\title{
LEAD AND COPPER REMOVAL FROM MULTI-METAL CONTAMINATED SOILS THROUGH SOIL WASHING TECHNIQUE USING HUMIC SUBSTANCES AS WASHING AGENTS: THE INFLUENCE OF THE WASHING SOLUTION pH
}

\author{
GIANINA ELENA DAMIAN ${ }^{a^{*}}, V_{\text {VAER MICLE }}^{a}$, IOANA MONICA SUR ${ }^{a}$
}

\begin{abstract}
The effect of three humic washing solution $\mathrm{pH}$ values $(3.0,7.0$ and 9.6-its natural $\mathrm{pH}$ ) on the removal efficiency of $\mathrm{Pb}$ and $\mathrm{Cu}$ from multimetal contaminated soil collected nearby "Larga de Sus" mine from Zlatna (Alba County, Romania) was investigated, at laboratory scale, by an ex-situ soil washing technique. In this study, a commercial soluble humic sample extracted from German Leonardite was used as washing agent to remove $\mathrm{Pb}$ and $\mathrm{Cu}$ from polluted soil. Soil washing experiments were conducted in a stirrer with orbital-rotation oscillation at a liquid/solid ratio (L/S ratio; $\mathrm{mL}: \mathrm{g}$ ) of $8: 1$, concentration of humic washing solution of $2 \%$ and various stirring times (4, 6, 12, 24 and 40 hours). The removal efficiency of $\mathrm{Cu}$ and $\mathrm{Pb}$ increased with increasing $\mathrm{pH}$ from 3.0 to 9.6 . In investigated experimental conditions, the best removal efficiencies $(60.3 \%$ in case of $\mathrm{Cu}$ and $48.08 \%$ in case of $\mathrm{Pb}$ ) were obtained at alkaline $\mathrm{pH}$ values of humic washing solution.
\end{abstract}

Keywords: humic substances, soil washing, heavy metals, washing solution pH

\section{INTRODUCTION}

Soil contamination with lead and copper is a worldwide concern associated with anthropogenic activity, especially with mining and metallurgical activity [1]. Up to now, there are a variety of decontamination methodologies for soil remediation. Soil washing, that generally uses chemical solutions to

\footnotetext{
a Technical University of Cluj-Napoca, Faculty of Materials and Environmental Engineering, Department of Environmental Engineering and Sustainable Development Entrepreneurship, 103-105 Muncii Ave, Cluj Napoca, Romania

*Corresponding author: gianina_In@yahoo.com
} 
extract heavy metals from soil, represents a valid, efficient, rapid, relatively inexpensive and very promising method for removing heavy metals from multi-metal contaminated soils, as reported by many researchers [2-6]. However, soil washing is a promising strategy if the applied extracting agent minimally changes the original solid matrix, original characteristics and does not leave toxic residues in the treated soil [7]. For these reasons, humic substances that are natural organic compounds ubiquitous in the environment [8] may have the potential of becoming extracting agents in soil washing technology because are environmentally benign, can support soil structure and improve soil physical, chemical and biological properties [9]. They have a strong propensity to form stable complexes with heavy metals cations in the $\mathrm{pH}$ range encountered in the soil environment [10]. Humic carboxylic $\mathrm{COOH}$ and phenolic - $\mathrm{OH}$ groups from their structure besides alcoholic and amin functional groups are mainly involved in the formation of metal-humic complexes [11].

However, the ability of humic substances to complex with cations is strongly $\mathrm{pH}$ dependent. Humic substances change their structure depending on $\mathrm{pH}$ and the type of metals present. Humic substances are made up of hundreds of different molecules of many different sizes with many ways to orient themselves by twisting, bending, compressing, and expanding. They are held together loosely by weak forces in a colloidal state. Slight changes in $\mathrm{pH}$ will actually cause the humic polymers to fracture, breaking up the original molecules. The fractured molecules are then free to associate with numerous other free radicals, metals or impurities. High $\mathrm{pH}$ makes humic substances open up their long-chain polymers, whereas low $\mathrm{pH}$ makes them close (aggregation of the humic molecules) [12]. Increasing the $\mathrm{H}^{+}$ concentration (decreasing $\mathrm{pH}$ ) causes the protonation of the humic carboxylic $\mathrm{COOH}$ groups, which eventually leads to precipitation - this usually begins at $\mathrm{pH} \sim 3-2$ and reaches completion at $\mathrm{pH} \sim 2-1$ [13]. The aggregation reduces the exposure of functional groups [12]. Deprotonating of these functional groups occurs at increasing $\mathrm{pH}$ and these behave as negatively charged moieties, attracting the positively charged heavy metal ions and protons (binding heavy metals) [14]. It is known that humic substances have a higher affinity for $\mathrm{Pb}^{2+}$ and $\mathrm{Cu}^{2+}$ that react with carboxylic and phenolic groups. The higher $\mathrm{pH}$ of the solution, the higher is the adsorption ability of the ions [15].

Therefore, investigating extractability of $\mathrm{Cu}$ and $\mathrm{Pb}$ from contaminated soil using humic substances solution as a function of washing solution $\mathrm{pH}$ is of great interest in terms of environmental impact of these metals and due to the ability of humic substances to change their structure for bounding $\mathrm{Cu}$ and $\mathrm{Pb}$ and others heavy metals as a function of $\mathrm{pH}$. 
Inspite of the fact that many researchers studied the potential of humic substances to extract heavy metals from contaminated soil through soil washing, investigating various factors affecting the process $[3-5,9,10$, $16]$, not much attention has been given to investigating the ability of humic substances to extract $\mathrm{Cu}$ and $\mathrm{Pb}$ from soil as a function of $\mathrm{pH}$ and on the effect of humic solution $\mathrm{pH}$ on the $\mathrm{Cu}$ and $\mathrm{Pb}$ removal efficiency $[6,17,18]$.

Consequently, the aim of the present research was to investigate the influence of the humic washing solution $\mathrm{pH}$ on the $\mathrm{Cu}$ and $\mathrm{Pb}$ removal from soil collected nearby "Larga de Sus" mine from Zlatna (Alba County, Romania) using commercial humic substances extracted from Leonardite as washing agent for contaminated soil and to extend the knowledge regarding the ability of humic substances to extract $\mathrm{Cu}$ and $\mathrm{Pb}$ from soils at various humic solution $\mathrm{pH}$ values.

\section{RESULTS AND DISCUSSION}

Soil characterization. The initial values of heavy metals concentration in the soil sample collected nearby "Larga de Sus" mine are significant and were compared with normal values and threshold limits established by Romanian legislation [19]. As it can be seen in Figure 1, the concentration of $\mathrm{Cu}$ and $\mathrm{Pb}$ exceeds more than 2 and 6 times the intervention threshold limit, respectively.

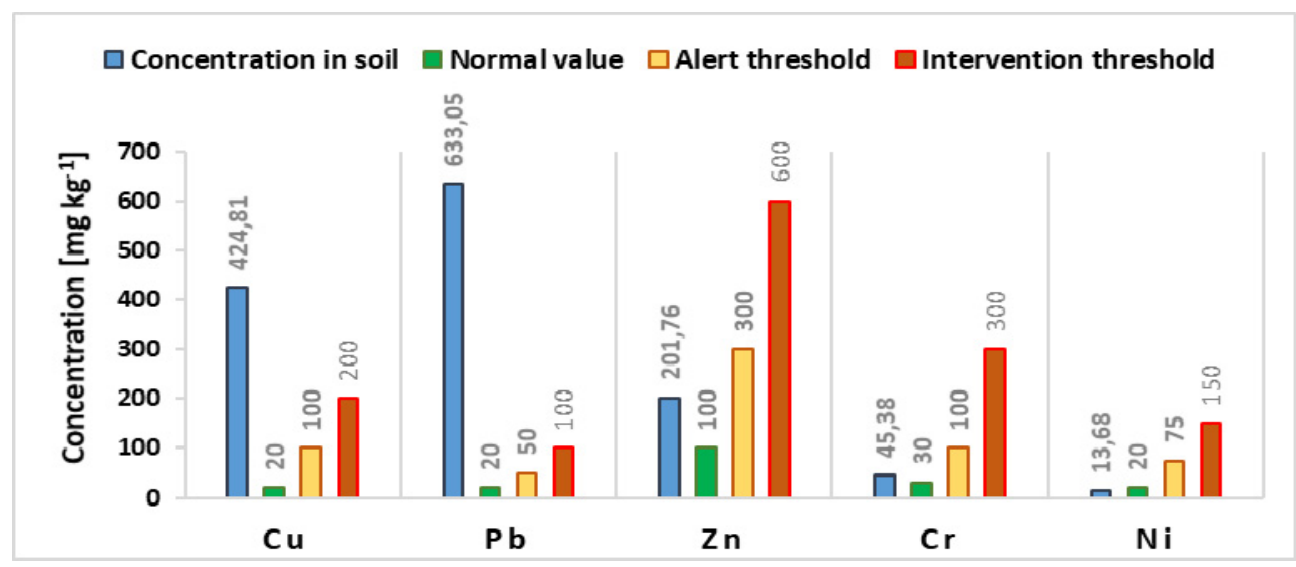

Figure 1. Heavy metals concentration of soil collected nearby "Larga de Sus" mine 
On the contrary, the concentration of $\mathrm{Zn}$ and $\mathrm{Cr}$ in soil sample used in washing experiments exceeds only the normal value of $\mathrm{Zn}$ and $\mathrm{Cr}$ stipulated by the same legislation, while $\mathrm{Ni}$ concentration doesn't exceed any limit established by Romanian legislation in case of $\mathrm{Ni}$.

According to the measured $\mathrm{pH}$ value, soil collected nearby "Larga de Sus" mine was classified as slightly acidic ( $\mathrm{pH}: 5.86)$.

Washing experiment results. The influence of the humic washing solution $\mathrm{pH}$ on the $\mathrm{Cu}$ and $\mathrm{Pb}$ removal efficiency from soil collected nearby "Larga de Sus" mine in comparison with blank samples (samples without humic substances) at various $\mathrm{pH}$ values, along stirring time is illustrated in Figure 2.

Along investigated stirring time, Cu removal efficiency from soil collected nearby "Larga de Sus" mine increase as the $\mathrm{pH}$ of the humic washing solution increase (Figure 2a). Highest Cu removal efficiency (60.3 $\%$ ) was observed in case of using humic washing solution at an alkaline $\mathrm{pH}$ (9.6-its natural $\mathrm{pH}$ ), while the lowest $\mathrm{Cu}$ removal efficiency, ranging from $1.1 \%$ to $18.7 \%$, was recorded in acidic conditions ( $\mathrm{pH}$ of humic washing solution: 3.0). Instead, in the absence of humic substances in the washing solution, when $\mathrm{pH}$ was increased, Cu removal efficiency from soil collected nearby "Larga de Sus" mine decreased (Figure 2a). In the absence of humic substances in the washing solution, when $\mathrm{pH}$ was increased from acidic to alkaline values, $\mathrm{Cu}$ removal efficiency decreased from values range between $38.3 \%$ and $43.2 \%$ to values range between $4.1 \%$ and $9.5 \%$, along investigated stirring time. This fact was expected as it is well known that using distilled water with strong acids as washing solution for heavy metal contaminated soil favors the extraction of heavy metals from soil. Similar percentages (40\%-61\%) were obtained by Moutsatsou et al. (2006) when studied the extractability of heavy metals from multi-metal contaminated soil using $1 \mathrm{M} \mathrm{HCl}$ as washing agent.

In the presence of humic substances in the washing solution, at $\mathrm{pH}$ 7.0 the Cu removal efficiency range from $10.4 \%$ to $27.4 \%$ along investigated stirring time, while in the absence of humic substances in the washing solution, Cu removal efficiency range from $22.7 \%$ to $26.5 \%$ along investigated stirring time.

The results indicated in Figure $2 \mathrm{a}$ also show that $\mathrm{Cu}$ removal efficiency was improved with more than 2 to 9 times when washing solution contained humic substances besides distilled water ( $\mathrm{pH}$ 9.6) unlike when measurements were made on samples in absence of humic substances.

But, in acidic conditions, Cu removal efficiency decreased by 2 to 38 times when washing solution contained humic substances besides distilled water and $\mathrm{HCl}$ than when the humic substances were missing from washing 
solution. The same fact was observed after $4,12,24$ and 40 hours at $\mathrm{pH} 7$. Thus, the ability of humic substances to remove $\mathrm{Cu}$ from soil is inhibited in acidic conditions (in the presence of $\mathrm{HCl}$ ). Others authors [17] have also reported similar findings for removal of $\mathrm{Cu}$ from soil by humic substances and suggested that the decreasing of $\mathrm{Cu}$ removal efficiency with decreasing the humic washing solution $\mathrm{pH}$ may be attributed to the fact that a low $\mathrm{pH}$ values ( $\mathrm{pH} 2-3)$, humic substances molecules become more compact, its functional groups (mainly humic carboxylic $-\mathrm{COOH}$ groups) involved in the formation of metal-humic complexes protonate and thus the ability of humic substances to attract the positively charged heavy metal ions is decreased [12-14]. Whereas, improved $\mathrm{Cu}$ removal efficiency at higher $\mathrm{pH}$ is due to the increased formation of Cu-humate complexes and because there is no strong competition from $\mathrm{H}^{+}$for $\mathrm{COOH}$ binding sites [17].

In the case of $\mathrm{Pb}$ (Figure 2b), at shorter stirring times (up to 6 hours), increasing humic washing solution $\mathrm{pH}$ to 9.6 does not led to an important increase in $\mathrm{Pb}$ removal efficiency. Instead, $\mathrm{Pb}$ removal efficiency even decreased with increasing $\mathrm{pH}$ of the humic washing solution. More accurate, $\mathrm{Pb}$ removal efficiency was $11.9 \%, 11.02 \%$ and $0.29 \%$ in the case of the $\mathrm{pH}$ of the humic washing solution of 3.0, 7.0 and 9.6, respectively. The same fact was observed in absence of humic substances along all investigated stirring time: as $\mathrm{pH}$ was increased, $\mathrm{Pb}$ removal efficiency decreased from values range between $14.6 \%$ and $37.9 \%$ to values range between $0.7 \%$ and $4.1 \%$.

But, at 6 hours of stirring, increasing humic washing $\mathrm{pH}$ from 3.0 to 9.6 led to an increase in $\mathrm{Pb}$ removal efficiency from $23.9 \%$ to $48.08 \%$. After 6 hours of stirring, the values of $\mathrm{Pb}$ removal efficiency obtained in case of humic washing solution at $\mathrm{pH} 3.0,7.0$ and $9.6(23.9 \%, 27.2 \%$ and $48.08 \%)$ are higher than the value obtained on samples in absence of humic substances $(17.1 \%, 11.7 \%$ and $1.54 \%)$. The improved $\mathrm{Pb}$ removal efficiency observed in the presence of humic substances at high $\mathrm{pH}$ values is because there is no strong competition from $\mathrm{H}^{+}$for $\mathrm{COOH}$ binding sites of the humic substances [17] and could be attributed to the fact that humic substances open up their long-chain polymers, the humic carboxylic - $\mathrm{COOH}$ groups deprotonate and behave as negatively charged moieties, attracting the positively charged $\mathrm{Pb}$ ions [12-14] increasing the formation of Pb-humate complexes.

After this stirring time, in the presence of humic substances in the washing solution, $\mathrm{Pb}$ removal efficiency does not follow the same trend. Thus, after 12 hours of stirring, $\mathrm{Pb}$ removal efficiency was highest at $\mathrm{pH} 3.0$ (35.4\%) and at $\mathrm{pH} 9.6(34.1 \%)$ than at $\mathrm{pH} 7.0$ (15.7\%). After 12 hours of stirring, at all investigated $\mathrm{pH}$ values, the $\mathrm{Pb}$ removal efficiency is higher in the presence of humic substances than in the absence of humic substances in washing solution (Figure $2 b$ ). 


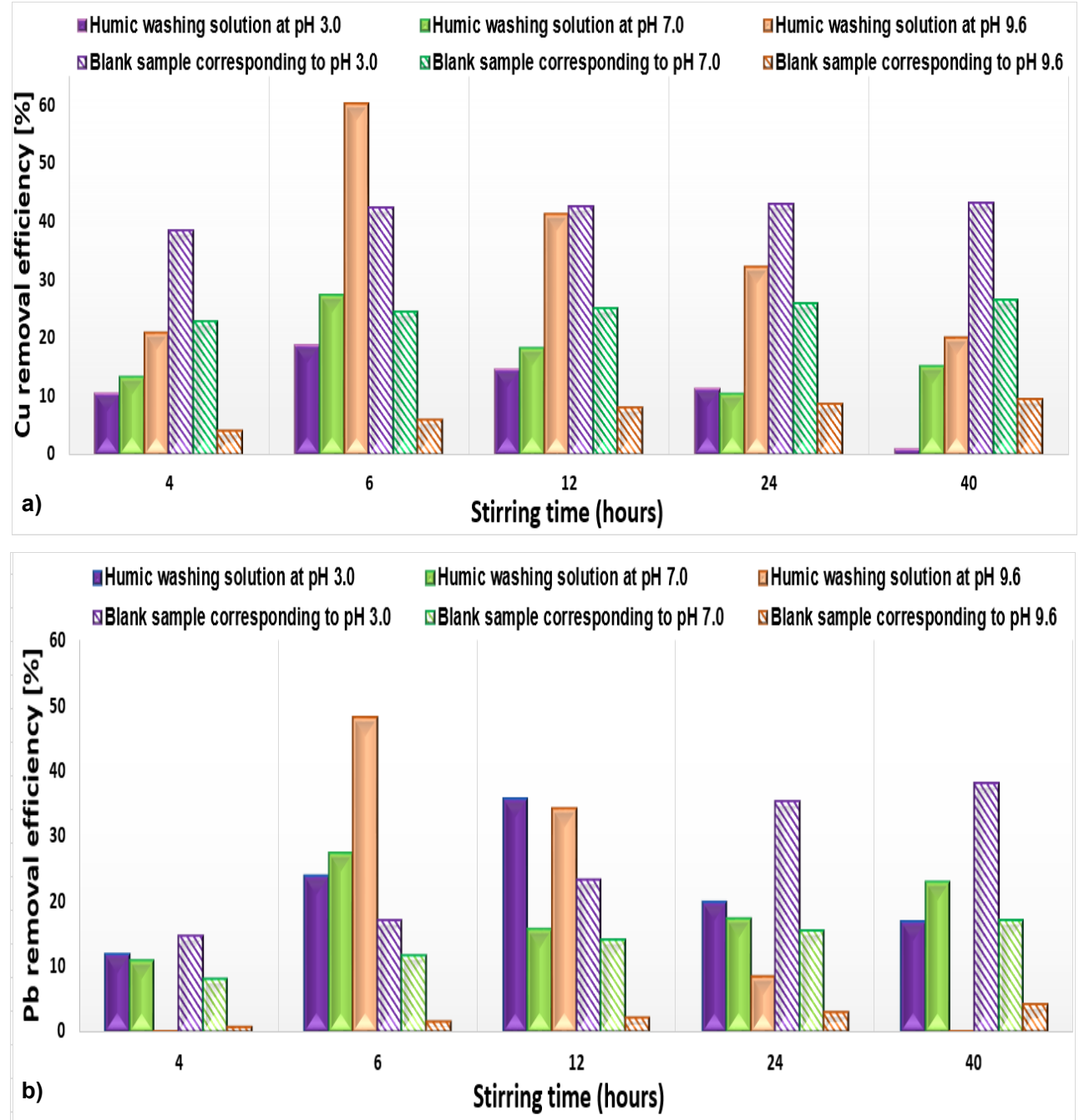

Figure 2. The effect of the washing solution $\mathrm{pH}$ on $\mathrm{Cu}(\mathrm{a})$ and $\mathrm{Pb}(\mathrm{b})$ removal efficiency from soil during investigated stirring time

After 24 hours of stirring, the $\mathrm{Pb}$ removal efficiency is higher in the presence of humic substances in washing solution than in the absence of humic substances in washing solution except for acidic conditions when the absence of humic substances in washing solution gave better results. In the presence of humic substances in the washing solution, $\mathrm{Pb}$ removal efficiency 
slightly increased with decreasing $\mathrm{pH}$ of the humic washing solution and after the investigated stirring time (40 hours), $\mathrm{Pb}$ removal efficiency was highest at $\mathrm{pH} 7.0(22.8 \%)$ than at $\mathrm{pH} 3.0$ and 9.6. Similar results were obtained by Kulikowska et al. (2015) that noted that $\mathrm{Pb}$ removal using humic substances from sewage sludge compost was highest at $\mathrm{pH} 7.0$ than at alkaline and acidic $\mathrm{pH}$ or having the same value on both acidic and alkaline conditions. Others authors reported that $\mathrm{Pb}$ removal efficiency with citric acid decreased with increasing $\mathrm{pH}$ (over $\mathrm{pH}=4.0$ ) [20]. Also, $\mathrm{Pb}$ solubility reached a maximum at $\mathrm{pH} 7.1$ and then decreased presenting insignificant alteration up to $\mathrm{pH}=8.9$ when $\mathrm{Pb}$ mobilization under $0.1 \mathrm{M}$ EDTA was studied [2].

The observed variation of $\mathrm{Pb}$ removal efficiency with $\mathrm{pH}$ along stirring time, in the presence of humic substances in the washing solution, indicates that the optimal $\mathrm{pH}$ for leaching $\mathrm{Pb}$ from soil collected from "Larga de Sus" mine using humic washing solution depends also on stirring time.

Thus, at shorter stirring times (up to 6 hours) and at longer stirring times (over 24 hours) acidic or neutral $\mathrm{pH}$ is more indicated for humic washing solution than alkaline $\mathrm{pH}$ in order to obtain highest $\mathrm{Pb}$ removal efficiencies, whereas between 6-12 hours of stirring alkaline $\mathrm{pH}$ would give better removal efficiencies than neutral and acidic $\mathrm{pH}$. Besides stirring time available and chosen for soil remediation, choosing the optimal $\mathrm{pH}$ of the humic washing solution for leaching $\mathrm{Pb}$ from soil collected from "Larga de Sus" mine should also depend on the optimal $\mathrm{pH}$ of the humic washing solution for leaching $\mathrm{Cu}$ and others heavy metals present in the soil sample.

Thus, after 6 hours of stirring, an alkaline $\mathrm{pH}(9.6)$ of the investigated humic washing solution would give the highest removal efficiency for both $\mathrm{Cu}$ and $\mathrm{Pb}(60.3 \%$ and $48.08 \%)$, whereas if only shorter stirring time is available for soil remediation (up to 4 hours), a neutral $\mathrm{pH}$ of the investigated humic washing solution will be best to effectively remove both $\mathrm{Cu}$ and $\mathrm{Pb}$ than acidic or alkaline $\mathrm{pH}$. But to generalize this statement, should also consider the influence of the humic washing solution $\mathrm{pH}$ on leaching others heavy metals or others pollutants present in the soil sample in order to achieve an effective and whole soil remediation.

The variation of $\mathrm{Cu}$ and $\mathrm{Pb}$ concentration from soil collected nearby "Larga de Sus" mine as a function of humic washing solution $\mathrm{pH}$, along stirring time is illustrated in Figure 3. 


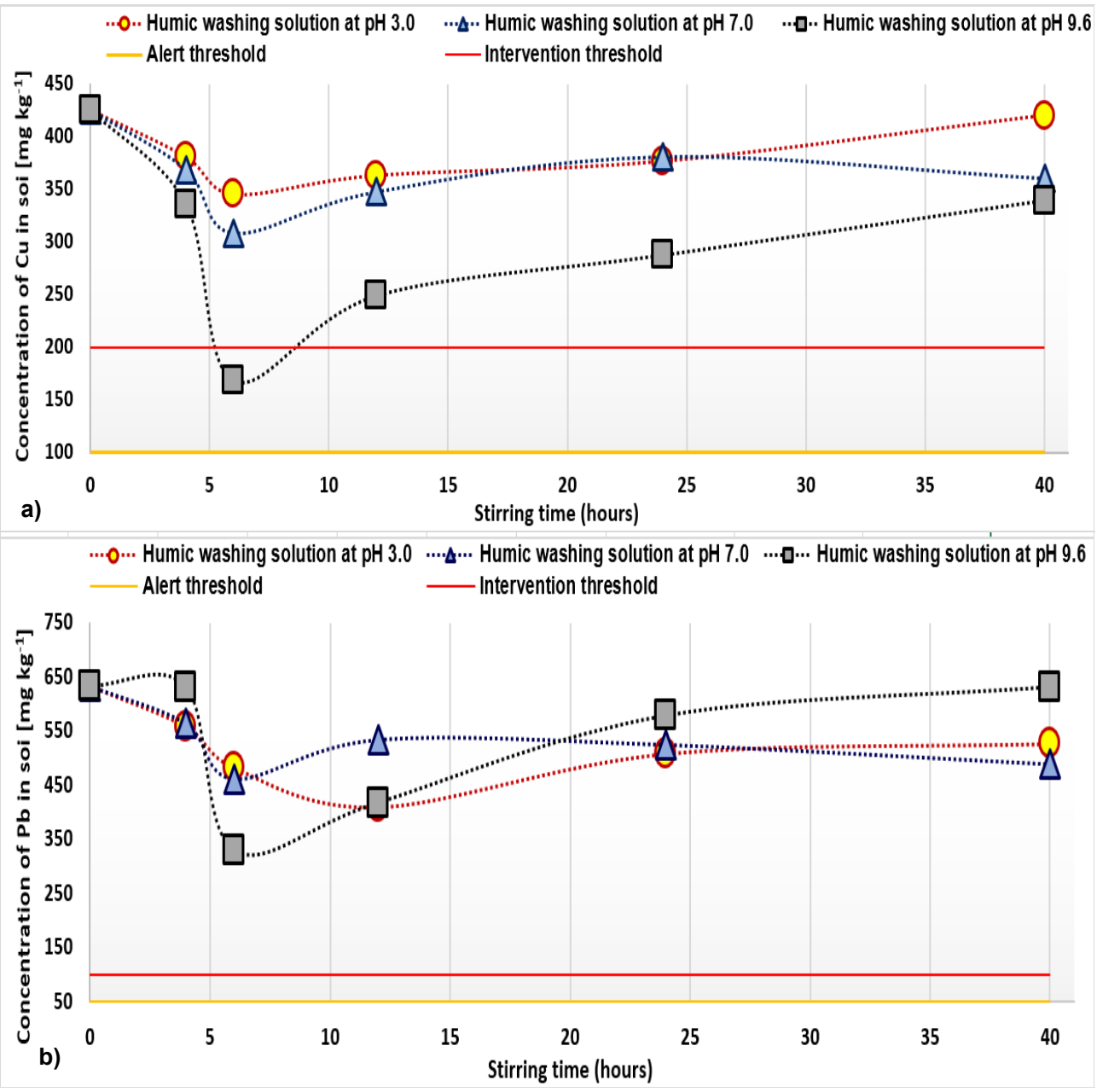

Figure 3. The variation of $\mathrm{Cu}(\mathrm{a})$ and $\mathrm{Pb}(\mathrm{b})$ concentration in soil during investigated stirring time as a function of humic washing solution $\mathrm{pH}$

In investigated experimental conditions, after 6 hours of stirring, the concentration of $\mathrm{Cu}$ from soil decreased with more than $30 \mathrm{mgkg}^{-1}$ below the intervention threshold limit $\left(200 \mathrm{mgkg}^{-1}\right)$ established by Romanian legislation [19] when $\mathrm{pH}$ of the humic washing solution was 9.6 (Figure 3a). The concentration of $\mathrm{Pb}$ from soil decreased to almost half of its initial value, after 6 hours of stirring, in case of humic washing solution with pH 9.6 (Figure 3b), but didn't decrease under the alert limits established by the same legislation. 
Along all investigated stirring time, when $\mathrm{pH}$ of the humic washing solution was decreased to neutral and acidic $\mathrm{pH}$ values, the limits established by the Romanian Legislation were reached neither in the case of $\mathrm{Cu}$ nor in the case of $\mathrm{Pb}$.

Thus, the removal of $\mathrm{Cu}$ and $\mathrm{Pb}$ from the soil collected from "Larga de Sus" mine in the presence of humic substances in washing solution is favored by high $\mathrm{pH}$ values of the washing solution. In the absence of humic substances in the washing solution, the removal of $\mathrm{Cu}$ and $\mathrm{Pb}$ from studied soil is favored by low $\mathrm{pH}$ values of the washing solution.

\section{CONCLUSIONS}

The present study has evidenced that $\mathrm{Cu}$ and $\mathrm{Pb}$ removal from soil collected nearby "Larga de Sus" mine from Zlatna (Alba County, Romania) using commercial humic substances extracted from Leonardite as washing agent is highly dependent on humic washing solution $\mathrm{pH}$ and on stirring time.

In the presence of humic substances in the washing solution, the $\mathrm{Cu}$ removal efficiency increase with increasing the $\mathrm{pH}$ of the humic washing solution. The highest Cu removal efficiency $(60.3 \%)$ was observed after 6 hours of stirring, in case of using humic washing solution at an alkaline $\mathrm{pH}$ (9.6-its natural $\mathrm{pH}$ ), while only $10.4-27.4 \%$ and $1.1-18.7 \%$ of $\mathrm{Cu}$ was leached at $\mathrm{pH} 7.0$ and 3.0, respectively. In the absence of humic substances in the washing solution, the highest $\mathrm{Cu}$ removal efficiency $(43.2 \%)$ was obtained in acidic conditions.

In case of $\mathrm{Pb}$, in the presence of humic substances in the washing solution, the results indicated that optimal $\mathrm{pH}$ for leaching $\mathrm{Pb}$ from soil collected from "Larga de Sus" mine depend more on stirring time, acidic or neutral $\mathrm{pH}$ being more indicated than alkaline $\mathrm{pH}$ up to 6 hours and over 24 hours of stirring. After 6 hours of stirring, an alkaline $\mathrm{pH}(9.6)$ of the investigated humic washing solution gave the highest removal efficiency for both $\mathrm{Cu}$ and $\mathrm{Pb}(48.08 \%)$. The values obtained after 6 hours of stirring are significantly higher in the presence of humic substances in washing solution $(\mathrm{pH}$ 9.6-natural $\mathrm{pH})$ than in the absence of humic substances in the washing solution ( $\mathrm{pH} 3.0)$, for both $\mathrm{Cu}$ and $\mathrm{Pb}$.

\section{EXPERIMENTAL SECTION}

Study area and sampling. The contaminated soil sample used in soil washing experiments was collected from 10-90 cm depth from a pasture located at about 800 meters downstream the "Larga de Sus" mine (Figure 4). 
The study area falls within the Zlatna mining perimeter located in South Apuseni Mountains (Alba County, Romania), where the extraction of gold-silver and polymetallic ores of $\mathrm{Cu}, \mathrm{Zn}$, and $\mathrm{Pb}$ date from the DacianRoman period [21].

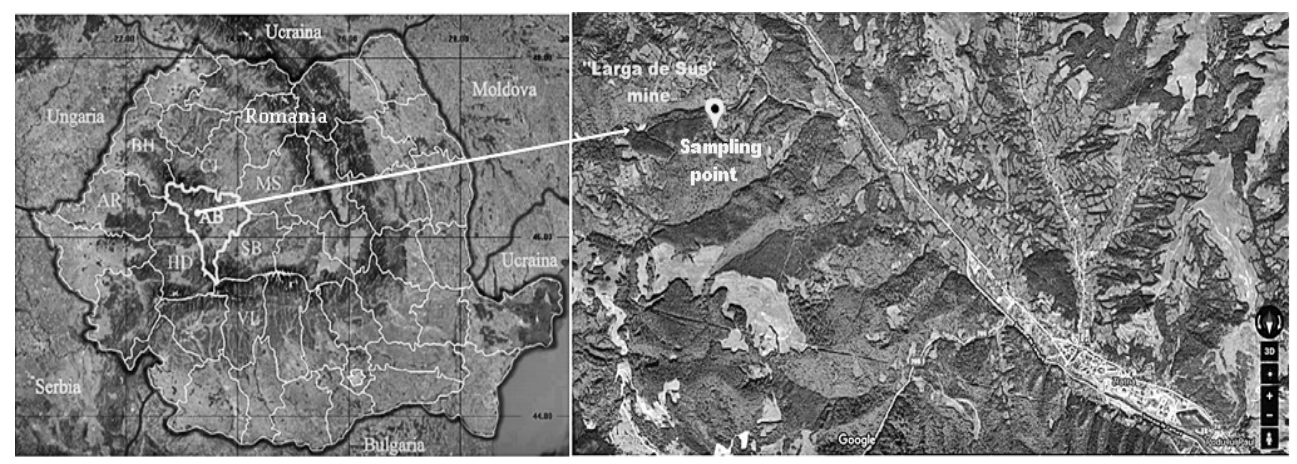

Figure 4. Location of the "Larga de Sus" mine and sampling point

Heavy metals concentration of the collected soil sample was determined through Atomic Absorption Spectrometry (AAS) using a SHIMADZU AA-6800 spectrometer.

Prior to the AAS analysis, the soil sample was dried at $95^{\circ} \mathrm{C}$, crumbled and milled to pass through a $250 \mu \mathrm{m}$ sieve. Then, $3 \mathrm{~g}$ of the processed sample was placed with $1 \mathrm{ml}$ distilled water, $21 \mathrm{ml}$ of concentrated $\mathrm{HCl}$ (Hydrochloric Acid) and $7 \mathrm{ml}$ of concentrated $\mathrm{HNO}_{3}$ (Nitric Acid) in a $100 \mathrm{ml}$ glass flask and left for mineralization for 2 hours (glass flask was heated on a sand bath).

The mineralised sample was then filtered into a $100 \mathrm{ml}$ volumetric flask, filled to the mark with distilled water and analysed for heavy metal concentration.

Reference solutions for spectrometer calibration were also prepared using analytical grade chemicals and distilled water.

Soil $\mathrm{pH}$ was measured in a suspension of soil and distilled water at a L/S ratio (mL:g) of 2.5:1 using a Hanna HI $3512 \mathrm{pH}$-meter.

Humic substance. The heavy metals concentration of the humic sample was determined by AAS. For the AAS analysis, humic sample, dissolved in distilled water in which was added hydrogen peroxide $\left(\mathrm{H}_{2} \mathrm{O}_{2}\right)$ at a humic substances solution: $\mathrm{H}_{2} \mathrm{O}_{2}$ ratio of 5:1, was mineralized for 1 hour on a sand bath. After cooling, mineralized sample was filtered through $0.45 \mu \mathrm{m}$ pore size filter into a $50 \mathrm{ml}$ glass flask and analysed for heavy metals concentration using a SHIMADZU AA-6800 spectrometer.

$\mathrm{pH}$ of the humic sample was measured using a Hanna $\mathrm{HI} 3512 \mathrm{pH}-$ meter in a suspension of humic substance and distilled water at a L/S ratio of 20:1 $\left(\mathrm{mLg}^{-1}\right)$. The results obtained are summarised in Table 1. 
Table 1. Characteristics of humic sample used for soil washing experiment

\begin{tabular}{|c|c|c|c|c|c|}
\hline Parameter & Unit & Value & Parameter & Unit & Value \\
\hline Water content & $\%$ & $17.7^{a}$ & $\mathrm{pH}$ & - & $9.60^{\mathrm{b}}$ \\
\hline \multirow{2}{*}{$\begin{array}{c}\text { Loss of ignition of dry } \\
\text { substance as humic acids }\end{array}$} & \multirow{2}{*}{$\%$} & \multirow{2}{*}{$70.7^{a}$} & $\mathrm{Cu}$ & $\mathrm{mg} \mathrm{L}^{-1}$ & $0,6785^{b}$ \\
\hline & & & $\mathrm{Pb}$ & $\mathrm{mg} \mathrm{L}^{-1}$ & $<\mathrm{IDL}^{* \mathrm{~b}}$ \\
\hline Calcium $(\mathrm{Ca})$ & $\mathrm{mgkg}^{-1}$ & $10300^{a}$ & $\mathrm{Ni}$ & $\mathrm{mg} \mathrm{L}^{-1}$ & $0,1433^{b}$ \\
\hline Potassium (K) & $\mathrm{mgkg}^{-1}$ & $99300^{a}$ & $\mathrm{Cr}$ & $\mathrm{mg} \mathrm{L}^{-1}$ & $<\mathrm{IDL}^{* \mathrm{~b}}$ \\
\hline Magnesium (Mg) & $\mathrm{mgkg}^{-1}$ & $1230^{\mathrm{a}}$ & $\mathrm{Zn}$ & $\mathrm{mg} \mathrm{L}^{-1}$ & $<\mathrm{IDL}^{* \mathrm{~b}}$ \\
\hline
\end{tabular}

a provided and determined by Humintech $\mathrm{GmbH}$ (supplier) through accredited laboratories

b determined

${ }^{*}$ IDL: Instrument detection limit

Soil washing experiment. The soil washing experiment using washing solution with humic substances and washing solution without humic substances (blank washing solution) was conducted at a L/S ratio of $8: 1\left(\mathrm{mLg}^{-1}\right)$ in a $100 \mathrm{ml}$ batch reactor with continuous orbital rotation-oscillation stirring at 100 oscillations/minute. Polluted soil was stirred with blank washing solution and $2 \%$ humic washing solution having different $\mathrm{pH}$ values $(3.0,7.0$ and 9.6) for different time intervals $(4,6,12,24$ and 40 hours) then samples were collected and filtered through $0.45 \mu \mathrm{m}$ pore size filter. The natural $\mathrm{pH}$ of the humic washing solution (9.6) was decreased to neutral and acidic values using concentrated $\mathrm{HCl}(35-38 \%), \mathrm{pH}$ being measured using a Hanna $\mathrm{HI} 3512 \mathrm{pH}$-meter. The $\mathrm{pH}$ of the blank washing solution was decreased with the same volume of concentrated $\mathrm{HCl}$ used to decrease the $\mathrm{pH}$ of the humic washing solution.

The concentration of $\mathrm{Cu}$ and $\mathrm{Pb}$ from treated soil samples was determined by AAS. For the AAS analysis, treated soil samples were subjected to the same processing steps as explained above.

Removal efficiency of metal ions by soil washing was calculated using the following equation [14]:

$$
\text { Removal efficiency }(\%)=\left[\left(C_{0}-C_{F}\right) / C_{0}\right] * 100
$$

where, $C_{0}$ is initial metals concentration $\left(\mathrm{mgkg}^{-1}\right)$ of soil, and $C_{F}$ is the final concentration of metals $\left(\mathrm{mgkg}^{-1}\right)$ in soil, after soil washing treatment.

All the experiments and analyses were performed in duplicate at $25^{\circ} \mathrm{C}$ and the average values were reported. All chemicals were of analytical grade or ultra-pure.

\section{ACKNOWLEDGMENTS}

The authors thank sales team from S.C. SEMPLANT ROMHOL S.R.L Company (Bucharest, Romania) and HUMINTECH GmbH Company (Grevenbroich, Germany), for supplying the soluble humic sample extracted from German Leonardite (commercially found as Powhumus WSG-85). 


\section{REFERENCES}

1. I.M. Sur, V. Micle, T. Gabor, Studia UBB Chemia, 2016, LXI (3), 355.

2. A. Moutsatsou, M. Gregou, D. Matsas, V. Protonotarios, Chemosphere, 2006, 63, 1632.

3. M. Soleimani, M.A. Hajabbasi, M. Afyuni, S. Akbar, Journal of Environmental Quality Abstract, 2010, 39, 855.

4. O.K. Borggaard, H.C.B. Hansen, P.E. Holm, J.K. Jensen, S.B. Rasmussen, N. Sabiene, L. Steponkaite, B.W. Strobel, Soil and Sediment Contamination: An International Journal, 2009, 18, 369.

5. O.K. Borggaard, P.E. Holm, J.K. Jensen, M. Soleimani, B.W. Strobel, Acta Agriculturae Scandinavica, Section B - Soil and Plant Science, 2011, 61, 577.

6. T. Yang, M.E. Hodson, Science of the Total Environment, 2019, 647, 290.

7. M. Race, R. Marotta, M. Fabbricino, F. Pirozzi, R. Andreozzi, L. Cortese, P. Giudicianni, Journal of Environmental Chemical Engineering, 2016, 4, 2878.

8. I.V. Perminova, K. Hatfield, "Use of Humic Substances to Remediate Polluted Environments: From Theory to Practice", Springer, Netherlands, 2005.

9. F. Meng, G. Yuan, J. Wei, D. Bi, Y.S. Ok, H. Wang, Chemosphere, 2017, 181, 461.

10. F. Meng, G. Yuan, J. Wei, D. Bi, Y.S. Ok, H. Wang, Environmental Science and Pollution Research, 2017, 24(29), 23006.

11. L. Boruvka, O. Drabek, Plant Soil and Environment, 2004, 50(8), 339.

12. L. Mayhew, Acres USA-A voice for eco-agriculture, 2004, 34, 8.

13. R. Wandruszka, Geochemical Transactions, 2000, 2, 6.

14. M. Bahemmat, M. Farahbakhsh, M. Kianirad, Journal of Hazardous Materials, 2016, 312, 307.

15. M. Ubner, "Interaction of Humic Substances with metal cations", Tallinn University of Technology, TUT Press, Tallinn, Estonia, 2004.

16. M.A. Shaker, H.M. albishri, Chemosphere, 2014, 111, 587.

17. D. Kulikowska, Z. M. Gusiatin, K. Bułkowska, B. Klik, Journal of Hazardous Materials, 2015, 300, 882.

18. D. Kulikowska, Z. M. Gusiatin, K. Bułkowska, K. Kierklo, Chemosphere, 2015, $136,42$.

19. Order No. 756 of November 3, 1997 for the Approval of the Regulation on Environmental Pollution Assessment. Eminent: Ministry of Waters, Forests and Environmental Protection. (Published in: Official Gazette No 303 bis of 6 November 1997).

20. M. Niinae, K. Nishigaki, K. Aoki, Materials Transactions, 2008, 49, 2377.

21. A.A. Keri, S. Avram, T. Rusu, ProEnvironment ProMediu, 2010, 3, 318. 